\title{
Acute effects of ethanol on fetal body composition and electrolyte content in the rat
}

\author{
HEBE GREIZERSTEIN and ERNEST ABEL \\ Research Institute on Alcoholism, Buffalo, New York 14203
}

\begin{abstract}
A single dose (oral) of $6 \mathrm{~g} / \mathrm{kg}$ of ethanol administered to pregnant rats on Day 20 produced a change in fetal body composition. Twenty-four hours after the ethanol administration, fetuses had higher water, higher $\mathrm{Mg}$, and lower lipid-free solid content compared with controls. The levels of $\mathrm{Na}, \mathrm{K}, \mathrm{Ca}$, and $\mathrm{Zn}$ and the lipid and ash content in the alcohol-treated fetuses were not significantly different from controls. Differences in $\mathrm{Na}, \mathrm{K}, \mathrm{Ca}, \mathrm{Mg}$, or $\mathrm{Zn}$ concentration in maternal plasma or in placenta composition between groups were also not significant.
\end{abstract}

The fetal alcohol syndrome refers to a pattern of effects in the offspring of alcoholic women consisting of intrauterine and postnatal growth deficiency, physical malformations, motor dysfunction, and mental retardation (Jones \& Smith, 1973). One of the most consistent features of this syndrome is pre- and postnatal growth retardation, an effect observed in both man (Jones \& Smith, 1973; Kaminski, Fumeau, \& Schwartz, 1978) and animals (Abel, 1979, in press; Abel \& Dintcheff, 1978; Chernoff, 1977; Randall, Taylor, \& Walker, 1977). In the present experiment, we examined the effects of a single acute exposure to alcohol on gestation Day 20 to determine if the growth effects of in utero exposure to ethanol were associated with observable changes in fetal body composition in the rat.

\section{METHOD}

Nulliparous Long-Evans hooded rats (Blue Spruce Farms, New York) approximately 100 days old and 6 days pregnant were housed individually and fed ad lib. On Day 20 they were randomly divided in two groups of six animals each. Group 1 was intubated with $6 \mathrm{~g} / \mathrm{kg}$ ethanol ( $30 \% \mathrm{~W} / \mathrm{V}$ in water), Group 2 received an isocaloric amount of sucrose solution. The dams were food deprived but had free access to drinking water. Twenty-four hours later, all animals were sacrificed. Maternal blood plasma was collected and centrifuged for the determination of ethanol and electrolytes ( $\mathrm{Na}, \mathrm{K}, \mathrm{Ca}, \mathrm{Mg}$, and $\mathrm{Zn})$.

Upon removal from the mother, the fetuses and placentas were weighed and immediately frozen in liquid nitrogen. A total of four fetuses and four placentas taken from the ends of each uterine horn were used for the analyses. Samples were kept at $-80^{\circ} \mathrm{C}$ until the time of the analyses. Fetuses were dried in an oven at $60^{\circ} \mathrm{C}$ for $24 \mathrm{~h}$ or until constant weight. Water content was calculated by the difference between fresh and dried weights. Lipids were extracted with $40 \mathrm{ml}$ of chloroform-methanol $(2: 1 \mathrm{~V} / \mathrm{V})$ for $24 \mathrm{~h}$ under agitation. Lipid content was calculated in two ways: (1) the weight of the

This project was supported in part by New York State Health Planning Commission Grant HRC 1179. We thank C. Wojtowicz, J. Kaminski, and D. Boyer for technical assistance. residue after the evaporation of the chloroform and methanol solution, and (2) the difference between dry and lipid-free solid weights. There was a good agreement $( \pm 2.0 \%)$ between the two measures. The lipid-free solid portion of the fetuses and of the thawed placentas were ashed in a muffle furnace at $550^{\circ} \mathrm{C}$ overnight. The composition of $\mathrm{Na}, \mathrm{K}, \mathrm{Ca}, \mathrm{Mg}$, and $\mathrm{Zn}$ in maternal plasma, fetuses, and placentas was determined by atomic absorption. The concentration of ethanol in maternal blood was determined by gas chromatography using n-propanol as internal standard.

\section{RESULTS}

The body weights of the alcohol-exposed fetuses were significantly lower compared to the body weights of control fetuses (Table 1).

The fetuses of mothers receiving an acute dose of alcohol had a significantly higher water content and a lower lipid-free solid content compared to controls. Group differences in lipid and ash content were not statistically significant.

Four dams had detectable amounts of ethanol in the blood at time of sacrifice $(21.1 \pm 4.0 \mathrm{mg} / 100 \mathrm{ml})$. The other two had negligible amounts $(<.5 \mathrm{mg} / 100 \mathrm{ml})$.

No significant group differences were detected in the electrolyte concentration of maternal plasma or in placentas (Table 2). The Mg content in the fetuses of

Table 1

Fetal Body Composition (Percent Total Body Weight)

\begin{tabular}{lccccr}
\hline & $\begin{array}{c}\text { Total Fetal } \\
\text { Weight }(\mathrm{g})\end{array}$ & Water & Lipids & $\begin{array}{c}\text { Lipid-Free } \\
\text { Solids }\end{array}$ & Ash \\
\hline & \multicolumn{5}{c}{ Alcohol Treatment (Six Litters) } \\
Mean & 7.27 & 87.9 & 1.32 & 10.9 & 1.21 \\
SE & .28 & .3 & .09 & .3 & .07 \\
& \multicolumn{5}{c}{ Sucrose Treatment (Six Litters) } \\
Mean & 8.03 & 87.1 & 1.27 & 11.6 & 1.36 \\
SE & .16 & .1 & .09 & .2 & .06 \\
$\mathrm{t}$ & $2.37 *$ & $2.60^{*}$ & .41 & $2.37^{*}$ & 1.65 \\
\hline Note-Total fetal weight is based on four fetuses. & ${ }^{*} p=.05$.
\end{tabular}


Table 2

Mean (and Standard Error) Electrolyte Composition

\begin{tabular}{|c|c|c|c|c|c|c|c|c|c|c|c|c|c|c|c|}
\hline \multirow{2}{*}{$\begin{array}{l}\text { Treat- } \\
\text { ment }\end{array}$} & \multicolumn{3}{|c|}{$\mathrm{Na}$} & \multicolumn{3}{|c|}{$\mathbf{K}$} & \multicolumn{3}{|c|}{$\mathrm{Ca}$} & \multicolumn{3}{|c|}{$\mathbf{M g}$} & \multicolumn{3}{|c|}{$\mathrm{Zn}$} \\
\hline & Mean & SE & $\mathbf{t}$ & Mean & SE & $t$ & Mean & SE & $\mathrm{t}$ & Mean & SE & $\mathbf{t}$ & Mean & SE & $\mathrm{t}$ \\
\hline & \multicolumn{15}{|c|}{ Maternal Rat Plasma (mEq/1) } \\
\hline $\begin{array}{l}\text { Ethanol } \\
\text { Sucrose }\end{array}$ & $\begin{array}{l}124.40 \\
118.20\end{array}$ & $\begin{array}{r}23.00 \\
9.50\end{array}$ & .25 & $\begin{array}{l}5.67 \\
5.74\end{array}$ & $\begin{array}{r}1.12 \\
.57\end{array}$ & .05 & $\begin{array}{l}3.25 \\
3.90\end{array}$ & $\begin{array}{l}.42 \\
.39\end{array}$ & 1.13 & $\begin{array}{l}1.28 \\
1.39\end{array}$ & $\begin{array}{l}.14 \\
.15\end{array}$ & .54 & $\begin{array}{l}.039 \\
.040\end{array}$ & $\begin{array}{l}.004 \\
.003\end{array}$ & .22 \\
\hline $\begin{array}{l}\text { Ethanol } \\
\text { Sucrose }\end{array}$ & $\begin{array}{l}6.93 \\
6.79\end{array}$ & $\begin{array}{l}.10 \\
.22\end{array}$ & .57 & $\begin{array}{l}5.33 \\
4.91\end{array}$ & $\begin{array}{l}.29 \\
.26\end{array}$ & 1.09 & $\begin{array}{c}\text { Placen } \\
.44 \\
.53\end{array}$ & $\begin{array}{l}\text { s (m) } \\
.01 \\
.04\end{array}$ & 2.09 & $\begin{array}{l}.89 \\
.86\end{array}$ & $\begin{array}{l}.01 \\
.03\end{array}$ & .79 & $\begin{array}{l}.029 \\
.027\end{array}$ & $\begin{array}{l}.001 \\
.002\end{array}$ & 1.17 \\
\hline & \multicolumn{15}{|c|}{ Fetuses $(\mathrm{mEq} / \mathrm{g})$} \\
\hline $\begin{array}{l}\text { Ethanol } \\
\text { Sucrose }\end{array}$ & $\begin{array}{l}5.86 \\
5.65\end{array}$ & $\begin{array}{l}.28 \\
.18\end{array}$ & .64 & $\begin{array}{l}4.13 \\
4.49\end{array}$ & $\begin{array}{l}.15 \\
.08\end{array}$ & 2.16 & $\begin{array}{l}4.17 \\
3.97\end{array}$ & $\begin{array}{l}.11 \\
.10\end{array}$ & 1.29 & $\begin{array}{l}1.22 \\
1.16\end{array}$ & $\begin{array}{l}.90 \\
.15\end{array}$ & $2.32 *$ & $\begin{array}{l}.033 \\
.032\end{array}$ & $\begin{array}{l}.001 \\
.001\end{array}$ & .60 \\
\hline
\end{tabular}

Note $-N=6$ for all groups. $\quad * p<.05$.

dams receiving ethanol was significantly higher than in the sucrose group. Ca was also elevated over the sucrose groups, although not significantly. There were no statistically significant differences in the content of the other measured electrolytes.

\section{DISCUSSION}

A single dose of ethanol on Day 20 of pregnancy in rats reduced fetal body weights and increased body water, lipidfree solid content, and whole body $\mathrm{Mg}$ content. Since both groups received the same isocaloric treatment, these differences cannot be attributed to maternal food intake. Fetal body content of the other electrolytes $(\mathrm{Na}, \mathrm{K}, \mathrm{Ca}$, and $\mathrm{Zn})$ was not affected. The content of all the measured electrolytes in maternal plasma and placentas was similar in all animals.

Acute alcohol administration has been shown to affect the concentrations of some of these electrolytes in plasma of adult rats (Kalant, Mons, \& Mahon, 1966). These changes take place 2-4 h after alcohol ingestion and are dose dependent. Although the dose of ethanol used in our study is known to produce peak blood alcohol levels of approximately $260 \mathrm{mg} / 100 \mathrm{ml}$ at $6 \mathrm{~h}$ postintubation (Abel, 1979), alcohol levels at time of sacrifice ( $24 \mathrm{~h}$ after intubation) in the present study were below $20 \mathrm{mg} / 100 \mathrm{ml}$.

In conclusion, alcohol ingestion during pregnancy affects body water, lipid-free solid content, and $\mathrm{Mg}$ levels in the fetal rat. In doing so, it may be responsible for the retarded fetal growth in the fetuses of animals and humans (Abel, 1979, in press; Abel \& Dintcheff, 1978; Chernoff, 1977; Jones \& Smith, 1973; Kaminski et al., 1978; Randall et al., 1977). Further studies of ethanol effects on the fetuses after administration of ethanol at low doses and/or chronic duration are clearly of interest.

\section{REFERENCES}

Abel, E. L. Prenatal effects of alcohol on adult learning in rats. Pharmacology, Biochemistry and Behavior, 1979, 10, 239.

AвEL, E. L. The fetal alcohol syndrome: Behavioral teratology. Psychological Bulletin, in press.

Abel, E. L., \& Dintcheff, B. A. Effects of prenatal alcohol exposure on growth and development in rats. Journal of Pharmacology and Experimental Therapy, 1978, 207, 916.

Chernoff, G. A. A mouse model of the fetal alcohol syndrome. Teratology, 1977, 11, 223.

Jones, K. L., \& Sмiтh, D. W. Recognition of the fetal alcohol syndrome in early infancy. Lancet, 1973, 2, 999.

Kalant, H., Mons, W., \& Mahon, M. A. Acute effects of ethanol on tissue electrolytes in the rat. Canadian Journal of Physiology and Pharmacology, 1966, 44, 1.

Kaminski, M., Fumeau, C., \& Schwartz, D. Alcohol consumption in pregnant women and outcome of pregnancy. Alcohol, $1978,2,155$

Randall, C. L., Taylor, W. J., \& Walker, D. W. Ethanolinduced malformations in mice. Alcohol, 1977, 1, 219.

(Received for publication August 14, 1979.) 